\title{
Immunopathogenesis of primary biliary cirrhosis: an old wives' tale
}

\author{
Daniel S Smyk1, Eirini I Rigopoulou ${ }^{2,3}$, Ana Lleo ${ }^{4,5}$, Robin D Abeles ${ }^{1}$, Athanasios Mavropoulos ${ }^{1,3}$, \\ Charalambos Billinis ${ }^{6}$, Pietro Invernizzi ${ }^{4,7}$ and Dimitrios P Bogdanos ${ }^{1 *}$
}

\begin{abstract}
Primary biliary cirrhosis (PBC) is a cholestatic liver disease characterised by the autoimmune destruction of the small intrahepatic bile ducts. The disease has an unpredictable clinical course, but may progress to fibrosis and cirrhosis. Although medical treatment with urseodeoxycholic acid is largely successful, some patients may progress to liver failure requiring liver transplantation. PBC is characterised by the presence of disease specific anti-mitochondrial (AMA) antibodies, which are pathognomonic for PBC development. The disease demonstrates an overwhelming female preponderance and virtually all women with PBC present in middle age. The reasons for this are unknown; however several environmental and immunological factors may be involved. As the immune systems ages, it become less self tolerant, and mounts a weaker response to pathogens, possibly leading to cross reactivity or molecular mimicry. Some individuals display immunological changes which encourage the development of autoimmune disease. Risk factors implicated in PBC include recurrent urinary tract infection in females, as well as an increased prevalence of reproductive complications. These risk factors may work in concert with and possibly even accelerate, immune system ageing, contributing to PBC development. This review will examine the changes that occur in the immune system with ageing, paying particular attention to those changes which contribute to the development of autoimmune disease with increasing age. The review also discusses risk factors which may account for the increased female predominance of PBC, such as recurrent UTI and oestrogens.
\end{abstract}

Keywords: ageing, apoptosis, autoantibody, autoimmunity, infection

\section{Introduction}

\section{Primary Biliary Cirrhosis: a disease of Women}

Primary biliary cirrhosis (PBC) is a chronic cholestatic liver disease of autoimmune origin, characterised by inflammatory destruction of the small intrahepatic bile ducts, and fibrosis which can progress to cirrhosis and subsequent liver failure [1-3]. Symptoms include fatigue, insomnia, pruritus, Sicca symptoms, and arthralgias. More severe symptoms relate to portal hypertension and hepatic decompensation [1-3]. PBC shows a high female preponderance, mainly affecting middle aged women [1-4]. The female to male ratio ranges from 9:1 to 20:1, which is relatively higher than other autoimmune diseases [2]. Diagnosis requires the presence of at least two

\footnotetext{
* Correspondence: dimitrios.bogdanos@kcl.ac.uk

'Institute of Liver Studies, King's College London School of Medicine at King's College Hospital and Kings College Hospital NHS Trust Foundation, London, SE5 9RS UK

Full list of author information is available at the end of the article
}

out of three of the following: antimitochondrial antibodies (AMA) in serum, biochemical markers of cholestasis, and characteristic histopathological features [2,5-7]. AMA and disease-specific anti-nuclear antibodies (ANA) are usually present at high titres $[2,5,6,8]$. Many 'non-autoimmune' liver disorders such as viral hepatitides and acute liver failure are characterised by the presence of autoantibodies, however, when AMA are present they are often suggestive of co-existing $\mathrm{PBC}$ [6,9-18]. In these non-autoimmune driven liver pathologies, it is not clear whether AMA or other autoantibodies just indicate immune dysregulation or are pathologically relevant [19-25].

AMA are present in $95 \%$ of $\mathrm{PBC}$ patients, with a specificity of nearly $100 \%[6,7,20,21,26,27]$, therefore true AMA-negative PBC can exist but is extremely rare [28]. AMA is primarily of the IgG isotype, however, IgA and IgM are also detected [5]. As the presence of AMA is so strongly associated with $\mathrm{PBC}$, it is generally viewed that 
asymptomatic patients who are AMA positive will eventually develop PBC $[29,30]$. Patients with PBC exhibit a multi-lineage response to the E2 subunit of the pyruvate dehydrogenase complex (PDC-E2), which involves AMA as well as autoreactive CD4 and CD8 responses [6,31-33]. Histological features typical for $\mathrm{PBC}$ include: destruction of biliary epithelial cells (BEC), loss of small bile ducts (ductopaenia) with portal inflammatory cell infiltration; and occasional granuloma formation $[1-3,34]$. The portal inflammation is comprised largely of CD4, CD8, and B cells, as characterised by immunohistochemistry $[2,33,35]$.

\section{PBC: A disease of the old}

$\mathrm{PBC}$ is overwhelmingly a disease of middle-aged and older females, and is virtually absent in the paediatric or adolescent population, although several case reports indicate the development of PBC in children [23,36-41]. On closer analysis, these cases rarely represent true (or confirmed) $\mathrm{PBC}$, with several of these cases representing AMA positivity in the absence of clinical evidence of disease [41], or AMA positivity in the presence of liver disease other than $\mathrm{PBC}[23,38]$. Other cases represent PBC-like disease, which result from genetic mutations in genes controlling immunological regulation $[36,40]$. For example, Aoki and colleague report the case of a six month old male with abnormal liver biochemistry, and AMA positivity [36]. Histology in that case was not characteristic of $\mathrm{PBC}$ and the child was eventually diagnosed with IL-2-receptor- alpha deficiency, which resulted in defects of $\mathrm{T}$ regulatory cells [36]. This is similar to another case report by Tsuda and colleagues, who noted AMA positivity in an 11 year old with IPEX syndrome, a congenital disorder of immune regulation [40]. Although AMA positivity is viewed as being predictive of eventual PBC development in adults, it is unclear as to whether this applies in the paediatric population.

Only two case reports indicate genuine cases of paediatric PBC. Melegh et al [39] notes the case of a six year old female with AMA positivity and histological features of $\mathrm{PBC}$, which progressed to fibrosis. The AMA reactivity in that case was atypical to most $\mathrm{PBC}$ cases, in that specificity was to PDC-E3 related subunit as well as anti-citrate synthase [39]. Dahlan and colleagues report $\mathrm{PBC}$ in two children, one at eleven years, and the other at 15 years [37]. Follow-up of the eleven year old showed that she progressed from stage II PBC at 16 years, to stage IV PBC at 21 years of age, when she was transplanted [37]. Interestingly, her 30 year old mother also had PBC. In summary, true paediatric PBC is exceedingly rare, and likely represents an aetiopathogenesis which is highly atypical compared to most cases of PBC.

\section{Why is PBC a disease of older women?}

Although the aetiopathogenesis of autoimmune gastrointestinal and liver diseases remains poorly understood, it is believed that genetic susceptibility, immune dysregulation and exposure to environmental triggers are responsible for antigen-specific immunological breakdown that lead to the development of the disease [22,42-51]. The exact mechanisms by which environmental agents can trigger immunological breakdown are not well defined, but in most cases self/non-self mimicry has been considered to be instrumental [52-60]. Various environmental triggers have been implicated in the development of PBC, including xenobiotics, infectious agents, and hormones $[49,52,61-71]$, but why PBC primarily affects women in their fifth or sixth decade is still unanswered.

This review will address the current evidence surrounding the high female preponderance of $\mathrm{PBC}$ within a particular age group. Current evidence relating to the ageing immune system suggests an increased risk of developing autoimmune disease in later life (Table 1). In addition, risk factors for $\mathrm{PBC}$, such as recurrent urinary tract infections (UTI), reproductive history and oestrogen deficiency, appear to increase the susceptibility towards disease development in females (Table 2).

\section{The ageing immune system and impaired regulatory mechanisms}

Out of all autoimmune diseases, PBC has one of the latest ages of onset, followed by systemic sclerosis and Sjogren's syndrome [72]. Intriguingly, Sjogren's syndrome (and to a lesser extent systemic sclerosis) coexist in a significant proportion of patients with $\mathrm{PBC}$. This raises the question as to what role immunosenescence', the term used to describe the ageing of the immune system, plays a role in the pathogenesis of these diseases. Immunosenescence begins in approximately the fifth or sixth decade of life, and is characterised by an age dependant, progressive decline in immunological functioning $[72,73]$. Immunological changes implicated in the development of immunosenescence include cumulative alterations in $\mathrm{B}$ and $\mathrm{T}$ cell populations, increased levels of memory cells producing Th1 and 2 cytokines and $\mathrm{T}$ cell dysfunction due to thymic degeneration $[73,74]$. It has been suggested that thymic degeneration with age may lead to an accumulation of $\mathrm{T}$ cells that are reactive to neo(auto)antigens [74] and therefore increase the likelihood of a breakdown in self tolerance, as well as susceptibility to disease-triggering infections.

Though the total $\mathrm{T}$ cell number does not appear to be significantly decreased with age, there is an alteration of T-cell receptor (TCR) signalling, as well as TCR reexpression, namely due to decreased CD28 expression 
Table 1 Features of immunological ageing seen in the cellular pathology of primary biliary cirrhosis (PBC).

\begin{tabular}{ll}
\hline Ageing Feature & Presence in PBC \\
\hline $\begin{array}{l}\text { Decreased regulatory T cell } \\
\text { (Treg) response }\end{array}$ & - Increased CD127 and decreased CD39 on CD8+ T cells \\
& -CD8+CD28- cells fail to display a regulatory response when incubated with IL-10 \\
Decreased telomere length & -Quantitative fluorescence in situ hybridisation has shown decreased telomere length in biliary epithelial cells \\
& (BEC) of primary biliary cirrhosis (PBC) patients \\
DNA damage & - gammaH2AX-DNA-damage-foci detected in BEC \\
Increased apoptosis & -Apoptotic marker BCl-2 in BEC (may increase PDC-E2 exposure) \\
& -Increased apoptotic marker CD95 (Fas) on BEC \\
& -Unmodified PDC-E2 found in apoptotic blebs (apotopes) in BEC \\
Increased cellular senescence & -Increased expression of senescence markers p16 and p21 in BEC \\
& -Decreased Ki67 expression in BEC, indicating decreased cellular proliferation \\
Increased autophagy & -Decreased Bmi-1 (senescence regulator) expression in BEC \\
\hline
\end{tabular}

Several features characterise an aged immune system, including changes in T cell response, decreased telomere length and DNA damage, as well as apoptosis and cellular senescence. These features have also been demonstrated in liver tissues from patients with PBC. These findings may, in part, explain why PBC patients often present in middle age, compared to other autoimmune diseases. Please see relevant sections in the text for more detailed descriptions.

[75]. CD28 is a co-stimulatory receptor involved in antigen-mediated $\mathrm{T}$ cell activation, proliferation and survival [76-78]. Virtually all naive $\mathrm{T}$ cells in the umbilical cord are CD28+ [79]. So called CD28 null cells (CD28-), which do not express the CD28 receptor, are functionally active oligoclonal lymphocytes that lack proliferative capacity, have reduced antigen receptor diversity and defective antigen induced proliferation hence are senescent cells $[76,78]$. It has emerged that the accumulation of CD28- cells occurs consistently with age, and CD28$\mathrm{T}$ cells are predictive of immune system incompetence in the elderly [76,78]. By the age of $80,10-15 \%$ of peripheral blood CD4+ and 50-60\% CD8+ T cells lack CD28 [78]. Increased CD28- cell accumulation is associated with a reduced response to pathogens and vaccines $[76,78]$, which is reflected in the low response to the influenza virus in the elderly [80]. In addition, CD28- cells have been found in patients with chronic inflammatory syndromes of all age groups, indicating a premature senescence of lymphocytes due to persistent immune activation [76,78]. Repeated stimulation of purified CD28+ cells with a specific antibody to the $\mathrm{T}$ cell receptor (TCR)/CD3 complex, results in decreased CD28 expression, and an increased proportion of CD28cells [76]. Increased stimulation with IL-15 and TNF- $\alpha$ has also been shown to augment the loss of CD28 [78]. The loss of CD28 is therefore characteristic of both ageing, as well as chronic inflammatory disease. CD8

Table 2 PBC risk factors associated with female sex and ageing

\begin{tabular}{|c|c|}
\hline Female Risk Factor & Significance \\
\hline Recurrent urinary tract infections & $\begin{array}{l}\text { Molecular mimicry and cross reactivity with bacterial (such as E. coli) peptides and PDC-E2 } \\
\text { epitopes }\end{array}$ \\
\hline Oestrogen deficiency & Increased propensity towards ductopaenia \\
\hline Increased incidence of vaginal infections & $\begin{array}{l}\text { Alterations in vaginal flora increase the risk of developing urinary tract infections, which } \\
\text { appear to play a role in PBC }\end{array}$ \\
\hline Ageing Risk Factors & Significance \\
\hline Decreased CD28 expression (especially in CD8+ cells) & Reduced regulatory $T$ cell function and reduced immune response to infections \\
\hline $\begin{array}{l}\text { Phenotypical alterations in CD8+ cells (such as } \\
\text { increased CD127, and decreased CD39) }\end{array}$ & Decreased T regulatory cell function \\
\hline $\begin{array}{l}\text { Increased telomere shortening from oxidative stress an } \\
\text { ongoing inflammation }\end{array}$ & Increased cellular senescence, autophagy and apoptosis \\
\hline Increased apoptosis & $\begin{array}{l}\text { Formation of apoptotic blebs (apotopes) increase exposure of mitochondrial antigens to } \\
\text { the immune system }\end{array}$ \\
\hline
\end{tabular}

Several risk factors related to female sex and increased age appear to be significant in the pathogenesis of primary biliary cirrhosis (PBC). Risks associated with females include recurrent urinary tract infections, oestrogen deficiency, and increased incidence of vaginal infections. Age related changes (which may increase risk for PBC development) include alterations in regulatory T cell function, increased senescence and autophagy, as well as apoptosis. 
+CD28- cells are more common in patients with autoimmune disease, and their increased effector functions may enhance autoimmune disease and inflammatory responses [78]. CD8+CD28- T cells accumulate due to normal ageing, but also reflect chronic infection with viruses such as Epstein-Barr virus, human immunodeficiency virus, and human cytomegalovirus [78,81]. The loss of immunological tolerance and increased susceptibility to infections is interesting in the case of PBC, as numerous infectious agents have been implicated in the immunopathogenesis of PBC, by mechanisms such as molecular mimicry and immunological cross-reactivity [47,58,62,82-91].

The changes noted above have not been specifically linked to $\mathrm{PBC}$, but do give a general view of immunological alterations which may contribute to autoimmunity as we progress in age (Table 1). However, several phenotypic and functional changes have been noted in the CD4 and CD8 population of PBC patients [92]. As mentioned, $\mathrm{PBC}$ is histologically characterised by a dense mononuclear cell infiltrate, populated largely by CD4 and CD8 T lymphocytes [1-3,34]. Additionally, higher numbers of CD4 and CD8 $\mathrm{T}$ lymphocytes are found in the liver than in the peripheral circulation of $\mathrm{PBC}$ patients [92]. This has led to the suggestion that CD8+ cells may mediate BEC damage [92]. Bernuzzi and colleagues examined CD8 $\mathrm{T}$ regulatory (Treg) cells in PBC patients, and found several phenotypic and functional alternations [92]. Phenotypically, CD8 Treg from PBC patients had increased CD127 and reduced CD39 expression [92]. As CD127 is a marker of effector function whilst CD39 is indicative of normal Treg function, this abnormal phenotype may be indicative of a failure of competent Treg functioning [92]. There was no significant difference noted in the number of CD8+CD28cells in PBC patients versus controls, however, CD8 +CD28- cells from PBC patients failed to exhibit a regulatory immune response after incubation with IL-10 [92]. Interestingly, CD4+CD25+ function was not altered in $\mathrm{PBC}$, which differs from other autoimmune disease [92]. These data indicate that alterations in CD8+Treg and failure of regulatory mechanisms are a feature of PBC.

\section{Telomere and Telomerase activity is altered in ageing and in $\mathrm{PBC}$}

Telomeres are located at the ends of chromosomes, are composed of repeated DNA sequences and ensure that each DNA replication cycle has been completed [93]. With each division, sequences of the telomeres are lost, forming the basis for the hypothesis that telomere shortening occurs with age. Moreover, the loss of telomere sequences can be accelerated through oxidative stress and inflammation [93]. Short or damaged telomeres may induce DNA breaks, initiate cell senescence, or induce apoptosis [93]. Senescence occurs at a particular telomere length, at which point the cell passes the so called 'mortality checkpoint 1', which is under control of p53 and Rb genes [93]. Further loss of telomere length and passage through mortality checkpoint 2 , will induce apoptosis [93]. These events could in turn result in a loss of immunological tolerance [93] and it has been observed that shortened telomere length is a feature of many autoimmune diseases [94-103] including PBC [104]. Of note, increased disease activity has been correlated with increased telomere shortening in systemic lupus erythematosus (SLE) [103].

Telomerase is an enzyme which prevents telomere shortening, and may also increase telomere length [93]. Telomerase activity varies among autoimmune diseases [93], for example, there is increased telomerase activity in SLE [105], RA [106], juvenile idiopathic arthritis [107] and adult onset still disease [108], whilst telomerase activity is unchanged in Wegener's granulomatosis [109], and even reduced in systemic sclerosis [106].

Shortened telomere length with associated cellular senescence has been well demonstrated in a study by Sasaki and colleagues [104]. In that study, the BEC telomere length of 13 PBC patients, as well as 13 control subjects (consisting of liver samples from healthy patients and chronic viral hepatitis), was examined using quantitative fluorescent in situ hybridisation [104]. In addition, immunohistochemical studies for the senescence markers p16INK4a and p21WAF/Cip1, as well as for DNA damage, were performed [104]. A significant decrease in telomere length was noted in damaged BEC from $\mathrm{PBC}$ patients, in comparison to histologically normal BEC in PBC patients and controls [104]. Immunohistochemistry demonstrated $\gamma \mathrm{H} 2 \mathrm{AX}-\mathrm{DNA}$ damaged foci in BEC of PBC patients, with cellular senescence confirmed by positive p16INK4a and p21WAF/Cip1 staining [104]. These changes were not observed in healthy or pathological controls, and suggest that telomere shortening with associated DNA damage and cellular senescence is a unique feature of damaged BEC in PBC [104]. It should be noted that it was not possible to correlate telomere length with age, due to the small cohort size and telomerase activity was not examined. Further confirmatory studies using a larger cohort, as well as an analysis of telomerase activity in the $\mathrm{BEC}$ of $\mathrm{PBC}$ patients is warranted.

\section{Senescence and autophagy}

Senescence is a delayed stress response, which is induced by factors such as telomere shortening, oxidative stress, and DNA damage [110,111]. Senescence may also be induced by ageing cells, as a mechanism for limiting the depletion of cells in ageing tissue [110]. Several studies have demonstrated that oxidative stress is an 
inducer of cell senescence in the BEC of PBC patients [104,112-114]. Sasaki et al [112] notes that cellular senescence in early-stage PBC was associated with an infiltration of myeloperoxidase-positive inflammatory cells, indicating oxidative stress. In that study, BEC showed increased p21WAF/Cip1 staining, and decreased Ki67 (a marker of proliferating cells) staining [112]. Another study by the same group examined the expression of the Bmi1 gene (which suppresses p16INK4a activity) in liver samples from 18 PBC cases, 19 pathological controls, and 16 healthy livers [114]. Bmi1 was significantly reduced in damaged $\mathrm{BEC}$ of $\mathrm{PBC}$ patients, compared to strong expression in the nuclei of control groups [114]. In addition, cultured mouse BEC subjected to oxidative stress from $\mathrm{H} 2 \mathrm{O} 2$ exposure had significantly decreased Bmil expression, and increased p16INK4a activity [114].

Senescence is of interest in the development of PBC for several reasons. Firstly, senescent cells promote an environment which is pro-inflammatory and pro-fibrotic through secretion of cytokines (such as IL-1 and IL-6) and chemokines (IL-8 and MCP-1) [46,111,115-118]. Secondly, the process of autophagy, or "self eating", is involved in the maintenance of senescence, and may provide a route for BEC damage, as well as exposure of autoantigens into an established inflammatory environment $[111,117,119]$. Autophagy is a process whereby intracellular proteins and organelles are degraded to suppress damage and maintain metabolism of senescent cells [120-123]. An immunohistochemical study by Sasaki and colleagues investigated whether autophagy was associated with senescence in PBC [119]. Liver samples from $37 \mathrm{PBC}$ and 75 controls were stained for autophagy markers LC3, cathepsin-D, and LAMP-1, as well as for senescence markers p16INK4a and p21WAF/ Cip1 [119]. LC3 expression was present in $90.5 \%$ of inflamed and $27.5 \%$ non-inflamed bile ducts of $\mathrm{PBC}$ patients [119]. LC3 also co-localised with cathepsin-D, LAMP-1, p16INK4a and p21WAF/Cip1 [119]. These findings were not observed in the control group. Cultured BEC subjected to oxidative stress (with hydrogen peroxide), DNA damage (with Etoposide), and serum deprivation, induced cellular senescence [119]. Inhibiting autophagy with 3-methyladenine also reduced stress induced senescence, including a reduction of senescence associated phenotype markers CCL2 and CX3CL1 [119]. Although senescence and autophagy may play a role in BEC damage and exposure of cryptic epitopes, the competitive process of apoptosis may also be implicated in the pathogenesis of $\mathrm{PBC}$.

\section{Apoptosis: potential source of autoantigens}

Alterations in the apoptotic process in $\mathrm{PBC}$ may provide a source for BEC autoantigens, as well as limiting the immune systems ability to clear infections. Cell shrinkage, chromatin condensation, DNA cleavage, and packaging of cellular material into apoptotic bodies called blebs are all features of apoptotic cells $[124,125]$. The apoptotic process may be initiated as an alternative to senescence and autophagy, by triggers such as cytotoxic or oxidative stress, cytokine deprivation, or genomic damage $[124,125]$. Apoptotic cells release "find me" signals such as soluble lysophosphatidylcholine, and "eat me" signals such as phosphatidylserine $[125,126]$. These signals are recognised by phagocytes, which bind the apoptotic cell $[125,126]$. Phagocytes which bind the apoptotic cell release anti-inflammatory cytokines such as IL-10, and also induce a reduction of inflammatory cytokines such as IL-1 $\beta$, TNF- $\alpha$, and IL-12 $[125,127,128]$. Deficiencies in this process may result in the release of cellular material, which could be presented by antigen presenting cells to autoreactive B and $\mathrm{T}$ cells, thereby provoking inflammation and autoantibody formation [124,125,129-131]. In addition, the apoptotic blebs appearing on the surface of apoptotic cells can act as a source of autoantigens [132-138].

Apoptosis has been shown to play a role in several autoimmune diseases, such as SLE [129-131,139-142] and PBC [111,132,134-136,142-144]. However, several unique characteristics are found in the apoptotic processes of PBC versus SLE. Lorenz and colleagues note an increased number of apoptotic peripheral lymphocytes from SLE patients in vitro, which relates to an in vivo increase in these cells activation [142]. Increased numbers of apoptotic cells were found in the skin of patients with cutaneous lupus, after exposure to UV light [141], and remnants of apoptotic cells were found in the germinal centres of lymph nodes in SLE patients [139]. Additionally, tingible body macrophages, which clear apoptotic cells in healthy individuals, were noted to have abnormal morphology in SLE patients [139]. It was demonstrated by Koga et al [143] that apoptosis is a feature of BEC in PBC patients. That study involved 35 PBC patients, 16 normal controls, and 17 chronic hepatitis C patients [143]. In situ nick-end labelling showed increased DNA fragmentation in BEC of PBC patients, and immunohistochemical analysis of $\mathrm{Bcl}-2$ showed that it was more frequently expressed in the $\mathrm{BEC}$ and hepatocytes of PBC patients [143]. Ten of the PBC patients underwent a second liver biopsy after treatment with urseodeoxycholic acid, the treatment of choice for $\mathrm{PBC}$, and it was found that there was decreased Bcl-2 expression in the BEC, and decreased DNA fragmentation [143]. Kuroki et al [144] also indicates that the Fas pathway of apoptosis may be involved in PBC, as BEC showed increased Fas (CD95) on their cell membranes.

Studies into apoptosic pathways in $\mathrm{PBC}$ have also provided interesting data in regards to why AMA are so 
highly specific for PBC. Odin and colleagues [136] note that the recognition of PDC-E2 still occurred in apoptotic BEC. The PDC-E2 was intact, as it had not been cleaved by caspases [136] and autoantibody recognition of PDC-E2 was also maintained due to a lack of glutathionylation [136]. Lleo et al [135] found that unmodified PDC-E2 localised into the apoptotic blebs in human intrahepatic BEC, called apotopes [135]. Sera from AMA positive individuals reacted with PDC-E2 on apoptotic BEC, demonstrating an accessibility of PDCE2 to the immune system [135]. The same group of investigators have also demonstrated that BEC apotopes in the presence of macrophages from $\mathrm{PBC}$ patients, as well as AMA, induced the production of inflammatory cytokines [134]. Finally, it has also been demonstrated that the phagocytosis of apoptotic BEC by BEC provides these cells with a source of mitochondrial self-peptide [132].

The studies mentioned so far in this review demonstrate that immunological changes which occur with age may promote an increased susceptibility for PBC development. Although these changes occur in normal ageing, it appears that they may be altered, or even accelerated in individuals with a genetic predisposition, or who are exposed to other triggers implicated in PBC development. Oxidative damage and decreased immunological tolerance open the door to the suggestion that infectious agents may also be involved in PBC development. Several features of the infectious model underlying $\mathrm{PBC}$ development appear to be unique to females, which may explain the female predominance of $\mathrm{PBC}$.

\section{Recurrent Urinary Tract Infections and E. coli}

Several large epidemiological studies have consistently indicated that recurrent UTIs are a risk factor for PBC development $[61,63,64,145]$. The association between UTI and PBC was first made by investigators at the Royal Free Hospital in London, who found an increased rate of bacteriuria in female $\mathrm{PBC}$ patients, compared to controls $[89,146]$. One study reported recurrent UTI in $19 \%$ of PBC patients, compared to $5-6 \%$ of controls [89]. $57 \%$ of patients also reported at least one bacteriuric episode and more than two episodes were reported in $26 \%$ of PBC patients [89]. Parikh-Patel and colleagues demonstrated a positive association between $\mathrm{PBC}$ and recurrent UTI [63]. A large and comprehensive study by Gershwin et al [145] demonstrated that 59\% of 1032 PBC patients reported UTI. A relatively recent study by Prince and co-workers [64] also demonstrated an association of PBC with UTI. That study involved one group of 318 PBC patients from a geographically defined area, and another involving 2258 patients recruited from a PBC support group [64]. Multivariate analysis showed an association between UTI and PBC in PBC patients from both groups, but not in a cohort of 3936 demographically matched controls [64].

The link between UTI and PBC has been limited, as it is unclear as to whether recurrent UTI preceded PBC diagnosis, or is sequelae of concomitant autoimmune disease, such as Sjögren's/Sicca syndrome. It could be argued that changes in mucosal immunity which occur in these conditions, increases the risk of developing UTI. However, a recent study by Varyani and colleagues [147] has demonstrated that UTI preceded the diagnosis of $\mathrm{PBC}$ in a large cohort of PBC patients. Using the General Practice Research Database, the investigators identified 800 PBC patients, 7991 matched controls from the general population and 12137 chronic liver disease control patients [147]. UTI had been diagnosed within one year prior to $\mathrm{PBC}$ diagnosis in $29 \%$ of $\mathrm{PBC}$ patients, compared to $22 \%$ of matched controls and $17 \%$ of chronic liver disease controls [147]. Within a five year period prior to diagnosis, 19\% of PBC patients had been diagnosed with UTI, compared to $14 \%$ of matched controls and $11 \%$ chronic liver disease controls [147]. Of note, the mean age of $\mathrm{PBC}$ diagnosis was 63 years [147]. Whether PBC patients are more prone to UTI, or whether the increased incidence of UTI in PBC patients is due to natural ageing is unknown, as the incidence of asymptomatic and symptomatic bacteriuria increases with age [148]. Escherichia coli (E. coli) is the most commonly identified organism, being isolated in $85.7 \%$ of male and female UTI patients aged 15-65 years, and in $74 \%$ of patients over 65 years [148].

$E$. coli has been identified as an organism of interest, due to its frequency as a causative organism in UTI and being implicated in up to $70 \%$ of PBC patients with recurrent UTI [89]. Early studies have been focused particularly on rough forms of $E$. coli and their relation to PBC $[86,89,149]$. We and others have investigated the role of microbial/self molecular mimicry and immunological cross-reactivity as a mechanism responsible for the induction of liver autoimmunity, including that seen in patients with PBC $[54,91,150-160]$. Support for the molecular mimicry hypothesis in $\mathrm{PBC}$ has been found on the experimental level, where sera from PBC patients react with both $E$. coli and human PDC-E2 [161]. Interestingly, sera from $52 \%$ of patients with $\mathrm{PBC}$ reacted with PDC-E2 in one cohort [162]. Several studies have noted a cross reactivity between antibodies in $\mathrm{PBC}$ patients with amino acid sequences inside the ATPdependant Clp protease of E. coli $[86,163,164]$. Similar lipoyl domain sequences are also found between $E$. coli and human PDC-E2 and these sequences are essential for $\mathrm{T}$ cell epitope recognition of PDC-E2 in humans and E. coli $[83,91]$. The same study found a strong association between this reactivity and a history of recurrent UTI [83]. Shimoda et al provided data clearly 
demonstrating that E.coli and human PDC-E2 homologues are targets of cross-reactive responses at the CD4 T-cell level $[91,165,166]$. Of note, these epidemiological and experimental studies demonstrate a potential link between two pathologies with a high female preponderance.

In addition to E. coli, Lactobacillus delbrueckii (L. delbrueckii) is emerging as an important organism in the link between recurrent UTI and PBC as it may be both synergistically and directly pathogenic. $L$. delbrueckii is a component of normal vaginal flora, and alterations in this flora may lead to recurrent vaginitis, which in turn may lead to colonisation by bacteria such as E. coli and hence recurrent UTIs [167]. Vaginitis and vaginal infection has also been noted as being more prevalent in PBC patients $[63,145]$. It is therefore plausible that $L$. delbrueckii contributes to the development of recurrent UTI, by creating an environment which is prone to colonisation by bacteria such as $E$. coli. In addition, recent studies have also demonstrated that $L$. delbrueckii can be a directly pathogenic organism of UTI in elderly women $[168,169]$.

Lactobacilli have also been linked to PBC development in a 39 year old female who received several Lactobacilli vaccinations for recurrent vaginitis [25]. AMA from this patient reacted against human PDC-E2, and was also cross reactive with beta-galactosidase of Lactobacillus delbrueckii [25]. It has been previously identified that $L$. delbrueckii contains epitopic regions which mimic PDCE2 [167]. Hence, in women, L. delbrueckii may be implicated directly, through molecular mimicry, and indirectly, by predisposing to recurrent UTI in the pathogenesis of PBC. Several other bacteria, viruses, and parasites are being investigated as potential triggers of $\mathrm{PBC}$ via molecular mimicry and cross reactivity, but one in particular, Novosphingobium aromaticivorans, may also be relevant to female preponderance.

\section{Novosphingobium aromaticivorans, oestrogen, and reproduction}

$N$. aromaticivorans is a gram negative bacteria found universally in air, soil, and water [170]. Of relevance to PBC this bacterium contains two proteins which share amino acid sequences with the immunodominant epitope of PDC-E2 [170]. $N$. aromaticivorans has also been found to induce $\mathrm{PBC}$-specific anti-mitochondrial antibodies in immunised mice that develop liver pathology with histological characteristics similar to that seen in PBC [171].

Several studies have indirectly alluded to oestrogen deficiency as a potential risk factor for PBC development $[61,64,145,172,173]$ and $N$. aromaticivorans has been shown to metabolize xenobiotics and oestrogen [174]
The intracellular pathways involving the stimulatory affects of oestrogen on cholangiocyte proliferation has been investigated by Alvaro and colleagues [174-176]. Animal models have shown that oestrogens and other growth factors induce cholangiocyte proliferation via activation of the Src/Shc/ERK molecular signalling cascade [176]. Alvaro and colleagues suggest that there is a synergistic role between oestrogens and growth factors in cholangiocyte proliferation [176]. Antagonists to oestrogen receptors (OR) also inhibit cholangiocyte proliferation and reduce expression of ERK/Shc [176]. Exogenous oestrogen administration with 17- $\beta$-oestradiol increases $\mathrm{Src} / \mathrm{Shc} / \mathrm{ERK}$ protein expression as well as cholangiocyte proliferation in vitro [176]. These results demonstrate that oestrogens likely play a role in cholangiocyte proliferation [174-176].

The same group of investigators also demonstrated a role for oestrogen in the progression of PBC [174]. Liver biopsies from $\mathrm{PBC}$ patients and controls (normal liver, primary sclerosing cholangitis and alcoholic cirrhosis) were immunohistochemically examined for oestrogen receptor alpha (OR- $\alpha)$, oestrogen receptor beta (OR- $\beta$ ), cytokeratin 19, proliferating cellular nuclear antigen (PCNA), and Fas by terminal deoxynucleotide transferase end labelling (TUNEL) [174]. OR- $\alpha$ and OR- $\beta$ were only found in PBC samples [174] and OR- $\beta$ was present in all histological PBC stages in $50-65 \%$ of $\mathrm{PBC}$ patients. OR- $\alpha$ expression varied based on histological stages, with OR- $\alpha$ being expressed in $1 \%$ of those in stage 1 , $12 \%$ in stage 3 , and absent in stage 4 [174]. This correlated with PCNA expression and maximal ductopaenia [174]. OR- $\alpha$ was significantly decreased in PBC compared to that seen in pathological controls [174]. These findings suggest that OR- $\alpha$ expression is reduced in advanced $\mathrm{PBC}$, which favours a progression towards ductopaenia [2,174]. Interestingly, an early study indicated that exogenous oestrogen administration improved liver biochemistry in PBC patients [177]. Those researchers noted a fall in serum enzymes at mid-menstrual cycle in untreated PBC patients [177]. Five PBC patients were administered ethinyl oestradiol: 1 premenopausal, 1 post-menopausal, and 3 post-oophorectomy [177]. Aspartate transaminase decreased by greater than $50 \%$ after 2 weeks of treatment in 4 of the 5 patients, $\gamma$ GT decreased by $50 \%$ in all 5 patients, and alkaline phosphatase decreased by $30 \%$ [177]. Repeated courses of oestradiol administration produced similar results [177]. Although this study was limited in terms of controls and cohort size, it is interesting given the more recent findings indicating the protective effects of oestrogen in $\mathrm{PBC}$, as well as a decrease in hormone replacement therapy reported in some studies $[64,145]$.

Apart from oestrogen, several characteristics in the obstetric histories of women with PBC are worth noting. 
Parikh-Patel and colleagues have noted an increased incidence of sexually transmitted infections in female PBC patients versus controls (18.5\% versus $10.4 \%)$, as well as an increase in vaginal infection $(63.4 \%$ versus $35.2 \%)[173]$. Epidemiological studies have also indicated that $\mathrm{PBC}$ patients tend to be younger at the time of their first pregnancy, as well as having an increased incidence of pregnancy termination and extrauterine pregnancy $[61,63,64,145]$. Investigation into the reproductive characteristics of PBC patients therefore warrants further study.

\section{Viruses and ageing in PBC}

Age related changes in the ability of antigen-specific cellular immune responses to clear viruses have been noted. This has led to the assumption that ageing as a risk for autoimmunity may be due to the inability to erase viral-triggered autoimmune responses [74,75]. Whether this is possible in the case of $\mathrm{PBC}$ is still unknown. Geographical, clinical, and experimental evidence has led to the suggestion that a viral cause may underline the development of $\mathrm{PBC}$ in some individuals $[178,179]$. Clusters of PBC have been noted among individuals who emigrate from areas with low $\mathrm{PBC}$ rates to areas with high $\mathrm{PBC}$ rates, and unrelated individuals living in the same household have developed the disease [178]. As well, recurrence of PBC after liver transplantation appears to occur earlier, and with a greater severity in patients treated with tacrolimus, and the opposite is observed with cyclosporine administration $[178,180]$. The group led by Mason and colleagues have found evidence of viral particles in the biliary epithelial cells of PBC patients, and antibody reactivity to retroviruses has been found in the sera of PBC patients [181]. This reactivity was found to be specific to viral proteins when reactivity to AMA was blocked out [182]. Genetic material of a human betaretrovirus (HBRV) (with 95\% homology to mouse mammary tumour virus, or MMTV) has been detected in the lymph nodes of $\sim 75 \%$ of PBC patients in a cohort of PBC patients [183]. Further analysis by immunohistochemistry also demonstrated HBRV material in the lymph nodes of PBC patients, which was not observed in controls [183]. However, lower detection rates were observed when hepatocytes were analyzed (only 30\%), as well as in other studies utilising a PCR approach $[183,184]$. Selmi et al [184] were unable to detect reactivity between PBC sera and a mouse MMTV, and no immunohistochemical or molecular evidence for MMTV was found in liver specimens. In contrast to this, Johal and colleagues found MMTV sequences in healthy liver tissues, in addition to liver tissue from a variety of liver diseases including PBC [185]. Selmi notes that reactivity between $\mathrm{PBC}$ sera and some viral proteins may be due to the presence of mitochondrial antigens in the viral preparations derived from murine MMTV [184]. However, the differing rates of viral detection from one study to the next may be due to differing methodological approaches [178]. Mason [178] highlights that studies by his group utilised a RT-PCR approach, which is more sensitive for detecting retroviral material than PCR which was used in the study by Selmi [184]. As well, other studies have not examined lymph node material from PBC patients, despite these tissues being the major reservoir for HBRV $[178,183]$. Lymph nodes co-cultured with normal cholangiocytes were shown to induce the expression of AMA-antigens on the cholangiocyte cell membrane [186]. Another study has demonstrated that HBRV infected cells expressed the PDC-E2 phenotype, and in vitro cell cultures were induced to express PDC-E2 when exposed to HBRV [187]. Of interest, a randomized controlled trial with anti-retroviral therapy is planned to treat patients with $\mathrm{PBC}$ who are unresponsive to UDCA $[178,188,189]$, although similar studies [190] have failed to reach non-histological endpoints utilized in clinical trials in PBC [191].

A viral role in the pathogenesis of $\mathrm{PBC}$ is still under debate [191]. Several factors may account for this, such as the fact that only a small number of studies have been performed, as well as the conflicting results generated by different groups [191]. As well, differences in experimental approach and design, as well as authors interpretation of the results, may also account for the inconclusive status of viruses in the pathogenesis of PBC [178]. Further studies are needed to provide a conclusion in either direction.

\section{Concluding Remarks}

Primary biliary cirrhosis is an autoimmune disease with a striking predominance in middle-aged females. Various genetic characteristics and environmental factors have been implicated in the disease development and progression. Factors, such as recurrent UTI and oestrogen signalling provide insight as to why females are more prone to $\mathrm{PBC}$. Studies characterising the decline of the immune system with age, have provided evidence as to why presentation with $\mathrm{PBC}$ often occurs in middle age. It is likely that genetic predisposition combined with environmental triggers act in a multiple hit model. These factors may also contribute to the decline of an already ageing immune system, through recurrent infections and inflammation, as well as oxidative damage. The immune system may then reach a critical stage where tolerance to self is lost. Increased cellular stresses via environmental or infectious triggers, may also 
contribute towards a propensity of apoptosis in the BEC, which allows for autoepitope exposure to the immune system.

\section{Abbreviations}

AMA: antimitochondrial antibodies; ANA: antinuclear antibodies; BEC: biliary epithelial cells; E.coli: Escherichia coli; FDR: first degree relatives; OR: oestrogen receptor; PBC: primary biliary cirrhosis; PDC: pyruvate dehydrogenase complex; RA: rheumatoid arthritis; SLE: systemic lupus erythematosus; TCR: T-cell receptor; UTI: urinary tract infections.

\section{Author details}

${ }^{1}$ Institute of Liver Studies, King's College London School of Medicine at King's College Hospital and Kings College Hospital NHS Trust Foundation, London, SE5 9RS UK. ²Department of Medicine, University of Thessaly Medical School, Viopolis, 41110, Larissa, Greece. ${ }^{3}$ Institute of Biomedical Research and Technology (BIOMED), CERETETH, 41222, Larissa, Greece. ${ }^{4}$ Center for Autoimmune Liver Diseases, Division of Internal Medicine, IRCCS Istituto Clinico Humanitas, Rozzano 20089, Italy. ${ }^{5}$ Department of Translational Medicine, Università degli Studi di Milano, Rozzano, Italy. ${ }^{6}$ Faculty of Veterinary Medicine, University of Thessaly, Karditsa, Greece. ${ }^{7}$ Division of Rheumatology, Allergy and Clinical Immunology, University of California at Davis, Davis, CA 95616, USA.

\section{Authors' contributions}

DSS wrote the first draft; Subsequent drafts were written by DSS, EIR and DPB, who had the overall supervision of the review processing; all authors edited the paper and approved its final version.

\section{Competing interests}

The authors declare that they have no competing interests.

Received: 26 September 2011 Accepted: 2 December 2011

Published: 2 December 2011

\section{References}

1. Hohenester S, Oude-Elferink RP, Beuers U: Primary biliary cirrhosis. Semin Immunopathol 2009, 31:283-307.

2. Kaplan MM, Gershwin ME: Primary biliary cirrhosis. N Engl J Med 2005, 353:1261-1273

3. Lindor KD, Gershwin ME, Poupon R, Kaplan M, Bergasa NV, Heathcote EJ: Primary biliary cirrhosis. Hepatology 2009, 50:291-308.

4. Selmi $C$, Invernizzi $P$, Keeffe EB, Coppel RL, Podda M, Rossaro L, Ansari AA, Gershwin ME: Epidemiology and pathogenesis of primary biliary cirrhosis. J Clin Gastroenterol 2004, 38:264-271.

5. Bogdanos DP, Baum H, Vergani D: Antimitochondrial and other autoantibodies. Clin Liver Dis 2003, 7:759-777, vi.

6. Bogdanos DP, Invernizzi P, Mackay IR, Vergani D: Autoimmune live serology: current diagnostic and clinical challenges. World J Gastroenterol 2008, 14:3374-3387.

7. Bogdanos DP, Komorowski L: Disease-specific autoantibodies in primary biliary cirrhosis. Clin Chim Acta 2011, 412:502-512

8. Neuberger J: Primary biliary cirrhosis. Lancet 1997, 350:875-879.

9. Liaskos C, Bogdanos DP, Rigopoulou El, Dalekos GN: Development of antimitochondrial antibodies in patients with autoimmune hepatitis: art of facts or an artifact? J Gastroenterol Hepatol 2007, 22:454-455.

10. Liaskos C, Bogdanos DP, Davies ET, Dalekos GN: Diagnostic relevance of anti-filamentous actin antibodies in autoimmune hepatitis. J Clin Pathol 2007, 60:107-108.

11. Dalekos GN, Bogdanos DP, Neuberger J: Celiac disease-related autoantibodies in end-stage autoimmune liver diseases: what is the message? Liver Int 2008, 28:426-428.

12. Bernal W, Meda F, Ma Y, Bogdanos DP, Vergani D: Disease-specific autoantibodies in patients with acute liver failure: the King's College London Experience. Hepatology 2008, 47:1096-1097, author reply 1097.

13. Bogdanos DP, Mieli-Vergani G, Vergani D: Autoantibodies and their antigens in autoimmune hepatitis. Semin Liver Dis 2009, 29:241-253.
14. Bogdanos DP, Mieli-Vergani G, Vergani D: Non-organ-specific autoantibodies in hepatitis $C$ virus infection: do they matter? Clin Infect Dis 2005, 40:508-510.

15. Bogdanos DP, Mieli-Vergani G, Vergani D: Non-organ-specific autoantibodies in children with chronic hepatitis $C$ virus infection. Clin Infect Dis 2004, 38:1505, author reply 1505-1506.

16. Bogdanos DP, Gilbert D, Bianchi I, Leoni S, Mitry RR, Ma Y, Mieli-Vergani G, Vergani D: Antibodies to soluble liver antigen and alpha-enolase in patients with autoimmune hepatitis. J Autoimmune Dis 2004, 1:4.

17. Bogdanos DP, Bianchi I, Ma Y, Mitry RR, Mieli-Vergani G, Vergani D: Targets of antibodies to soluble liver antigen in patients with autoimmune hepatitis. Clin Chem 2004, 50:682-683, author reply 683-684

18. Van Norstrand MD, Malinchoc M, Lindor KD, Therneau TM, Gershwin ME, Leung PS, Dickson ER, Homburger HA: Quantitative measurement of autoantibodies to recombinant mitochondrial antigens in patients with primary biliary cirrhosis: relationship of levels of autoantibodies to disease progression. Hepatology 1997, 25:6-11

19. Rigopoulou El, Davies ET, Pares A, Zachou K, Liaskos C, Bogdanos DP, Rodes J, Dalekos GN, Vergani D: Prevalence and clinical significance of isotype specific antinuclear antibodies in primary biliary cirrhosis. Gut 2005, 54:528-532.

20. Rigopoulou El, Davies ET, Bogdanos DP, Liaskos C, Mytilinaiou M, Koukoulis GK, Dalekos GN, Vergani D: Antimitochondrial antibodies of immunoglobulin G3 subclass are associated with a more severe disease course in primary biliary cirrhosis. Liver Int 2007, 27:1226-1231.

21. Rigopoulou El, Bogdanos DP, Liaskos C, Koutsoumpas A, Baum H, Vergani D, Dalekos GN: Anti-mitochondrial antibody immunofluorescent titres correlate with the number and intensity of immunoblot-detected mitochondrial bands in patients with primary biliary cirrhosis. Clin Chim Acta 2007, 380:118-121

22. Vergani D, Longhi MS, Bogdanos DP, Ma Y, Mieli-Vergani G: Autoimmune hepatitis. Semin Immunopathol 2009, 31:421-435.

23. Hannam S, Bogdanos DP, Davies ET, Hussain MJ, Portmann BC, MieliVergani G, Vergani D: Neonatal liver disease associated with placental transfer of anti-mitochondrial antibodies. Autoimmunity 2002, 35:545-550

24. Ma Y, Okamoto M, Thomas MG, Bogdanos DP, Lopes AR, Portmann B, Underhill J, Durr R, Mieli-Vergani G, Vergani D: Antibodies to conformational epitopes of soluble liver antigen define a severe form of autoimmune liver disease. Hepatology 2002, 35:658-664

25. Bogdanos D, Pusl T, Rust C, Vergani D, Beuers U: Primary biliary cirrhosis following Lactobacillus vaccination for recurrent vaginitis. J Hepatol 2008, 49:466-473.

26. Dahnrich C, Pares A, Caballeria L, Rosemann A, Schlumberger W, Probst C, Mytilinaiou M, Bogdanos D, Vergani D, Stocker W, Komorowski L: New ELISA for detecting primary biliary cirrhosis-specific antimitochondrial antibodies. Clin Chem 2009, 55:978-985

27. Gabeta S, Norman GL, Liaskos C, Papamichalis PA, Zografos T, Garagounis A Rigopoulou El, Dalekos GN: Diagnostic relevance and clinical significance of the new enhanced performance M2 (MIT3) ELISA for the detection of $\lg A$ and $\lg G$ antimitochondrial antibodies in primary biliary cirrhosis. $J$ Clin Immunol 2007, 27:378-387.

28. Vergani D, Bogdanos DP: Positive markers in AMA-negative PBC. Am J Gastroenterol 2003, 98:241-243.

29. Metcalf JV, Mitchison HC, Palmer JM, Jones DE, Bassendine MF, James OF: Natural history of early primary biliary cirrhosis. Lancet 1996, 348:1399-1402

30. Mitchison HC, Bassendine MF, Hendrick A, Bennett MK, Bird G, Watson AJ, James OF: Positive antimitochondrial antibody but normal alkaline phosphatase: is this primary biliary cirrhosis? Hepatology 1986, 6:1279-1284

31. Bogdanos DP, Liaskos C, Rigopoulou El, Dalekos GN: Anti-mitochondrial antibodies in patients with systemic lupus erythematosus: revealing the unforeseen. Clin Chim Acta 2006, 373:183-184, author reply 185.

32. Bogdanos DP, Pares A, Rodes J, Vergani D: Primary biliary cirrhosis specific antinuclear antibodies in patients from Spain. The American journal of gastroenterology 2004, 99:763-764, author reply 765 .

33. Gershwin ME, Mackay IR: Primary biliary cirrhosis: paradigm or paradox for autoimmunity. Gastroenterology 1991, 100:822-833.

34. Van de Water J, Ansari A, Prindiville T, Coppel RL, Ricalton N, Kotzin BL, Liu S, Roche TE, Krams SM, Munoz S, Gershwin ME: Heterogeneity of 
autoreactive T cell clones specific for the E2 component of the pyruvate dehydrogenase complex in primary biliary cirrhosis. J Exp Med 1995, 181:723-733.

35. Harada K, Van de Water J, Leung PS, Coppel RL, Ansari A, Nakanuma Y, Gershwin ME: In situ nucleic acid hybridization of cytokines in primary biliary cirrhosis: predominance of the Th1 subset. Hepatology 1997, 25:791-796.

36. Aoki CA, Roifman CM, Lian ZX, Bowlus CL, Norman GL, Shoenfeld Y, Mackay IR, Gershwin ME: IL-2 receptor alpha deficiency and features of primary biliary cirrhosis. J Autoimmun 2006, 27:50-53.

37. Dahlan Y, Smith L, Simmonds D, Jewell LD, Wanless I, Heathcote EJ, Bain VG: Pediatric-onset primary biliary cirrhosis. Gastroenterology 2003, 125:1476-1479.

38. Gregorio GV, Portmann B, Mowat AP, Vergani D, Mieli-Vergani G: A 12-yearold girl with antimitochondrial antibody-positive autoimmune hepatitis. J Hepatol 1997, 27:751-754

39. Melegh B, Skuta G, Pajor L, Hegedus G, Sumegi B: Autoantibodies against subunits of pyruvate dehydrogenase and citrate synthase in a case of paediatric biliary cirrhosis. Gut 1998, 42:753-756.

40. Tsuda M, Torgerson TR, Selmi C, Gambineri E, Carneiro-Sampaio M, Mannurita SC, Leung PS, Norman GL, Gershwin ME: The spectrum of autoantibodies in IPEX syndrome is broad and includes antimitochondrial autoantibodies. J Autoimmun 2010, 35:265-268.

41. Zamfir O, Briaud I, Dubel L, Ballot E, Johanet C: Anti-pyruvate dehydrogenase autoantibodies in extrahepatic disorders. J Hepatol 1999, 31:964-965.

42. Longhi MS, Hussain MJ, Bogdanos DP, Quaglia A, Mieli-Vergani G, Ma Y, Vergani D: Cytochrome P450IID6-specific CD8 T cell immune responses mirror disease activity in autoimmune hepatitis type 2. Hepatology 2007, 46:472-484.

43. Ma Y, Bogdanos DP, Hussain MJ, Underhill J, Bansal S, Longhi MS, Cheeseman P, Mieli-Vergani G, Vergani D: Polyclonal T-cell responses to cytochrome P450IID6 are associated with disease activity in autoimmune hepatitis type 2. Gastroenterology 2006, 130:868-882.

44. Longhi MS, Ma Y, Mitry RR, Bogdanos DP, Heneghan M, Cheeseman P, Mieli-Vergani G, Vergani D: Effect of CD4+ CD25+ regulatory T-cells on CD8 T-cell function in patients with autoimmune hepatitis. J Autoimmun 2005, 25:63-71.

45. Longhi MS, Ma Y, Bogdanos DP, Cheeseman P, Mieli-Vergani G, Vergani D: Impairment of $\mathrm{CD} 4(+) \mathrm{CD} 25(+)$ regulatory T-cells in autoimmune liver disease. J Hepatol 2004, 41:31-37.

46. Shimoda S, Harada K, Niiro H, Yoshizumi T, Soejima Y, Taketomi A, Maehara Y, Tsuneyama K, Nakamura M, Komori A, et al: Biliary epithelial cells and primary biliary cirrhosis: the role of liver-infiltrating mononuclear cells. Hepatology 2008, 47:958-965.

47. Selmi C, Gershwin ME: Bacteria and human autoimmunity: the case of primary biliary cirrhosis. Curr Opin Rheumatol 2004, 16:406-410

48. Selmi C, Mackay IR, Gershwin ME: The immunological milieu of the liver. Semin Liver Dis 2007, 27:129-139.

49. Selmi C, Meda F, Kasangian A, Invernizzi P, Tian Z, Lian Z, Podda M, Gershwin ME: Experimental evidence on the immunopathogenesis of primary biliary cirrhosis. Cell Mol Immunol 2010, 7:1-10.

50. Hirschfield GM, Invernizzi P: Progress in the genetics of primary biliary cirrhosis. Semin Liver Dis 2011, 31:147-156.

51. Hirschfield GM, Heathcote EJ, Gershwin ME: Pathogenesis of cholestatic liver disease and therapeutic approaches. Gastroenterology 2010, 139:1481-1496.

52. Amano K, Leung PS, Xu Q, Marik J, Quan C, Kurth MJ, Nantz MH, Ansari AA, Lam KS, Zeniya M, et al: Xenobiotic-induced loss of tolerance in rabbits to the mitochondrial autoantigen of primary biliary cirrhosis is reversible. J Immunol 2004, 172:6444-6452.

53. Van de Water J, Turchany J, Leung PS, Lake J, Munoz S, Surh CD, Coppel R, Ansari A, Nakanuma Y, Gershwin ME: Molecular mimicry in primary biliary cirrhosis. Evidence for biliary epithelial expression of a molecule crossreactive with pyruvate dehydrogenase complex-E2. J Clin Invest 1993, 91:2653-2664

54. Van de Water J, Ishibashi H, Coppel RL, Gershwin ME: Molecular mimicry and primary biliary cirrhosis: premises not promises. Hepatology 2001, 33:771-775.

55. Koutsoumpas A, Polymeros D, Tsiamoulos Z, Smyk D, Karamanolis G Triantafyllou K, Rigopoulou El, Forbes A, Vergani D, Bogdanos DP, Ladas SD:
Peculiar antibody reactivity to human connexin 37 and its microbial mimics in patients with Crohn's disease. J Crohns Colitis 2011, 5:101-109.

56. Polymeros D, Bogdanos DP, Day R, Arioli D, Vergani D, Forbes A: Does cross-reactivity between mycobacterium avium paratuberculosis and human intestinal antigens characterize Crohn's disease? Gastroenterology 2006, 131:85-96.

57. Koutsoumpas A, Mytilinaiou M, Polymeros D, Dalekos GN, Bogdanos DP: Anti-Helicobacter pylori antibody responses specific for VacA do not trigger primary biliary cirrhosis-specific antimitochondrial antibodies. Eur J Gastroenterol Hepatol 2009, 21:1220.

58. Bogdanos DP, Choudhuri K, Vergani D: Molecular mimicry and autoimmune liver disease: virtuous intentions, malign consequences. Liver 2001, 21:225-232.

59. Bogdanos DP, Mieli-Vergani G, Vergani D: Virus, liver and autoimmunity. Dig Liver Dis 2000, 32:440-446.

60. Wen L, Ma Y, Bogdanos DP, Wong FS, Demaine A, Mieli-Vergani G, Vergani D: Pediatric autoimmune liver diseases: the molecular basis of humoral and cellular immunity. Curr Mol Med 2001, 1:379-389.

61. Corpechot C, Chretien Y, Chazouilleres O, Poupon R: Demographic, lifestyle, medical and familial factors associated with primary biliary cirrhosis. Journal of hepatology 2010, 53:162-169.

62. Gershwin ME, Mackay IR: The causes of primary biliary cirrhosis: Convenient and inconvenient truths. Hepatology 2008, 47:737-745.

63. Parikh-Patel A, Gold EB, Worman H, Krivy KE, Gershwin ME: Risk factors for primary biliary cirrhosis in a cohort of patients from the united states. Hepatology 2001, 33:16-21.

64. Prince MI, Ducker SJ, James OF: Case-control studies of risk factors for primary biliary cirrhosis in two United Kingdom populations. Gut 2010, 59:508-512.

65. Smyk D, Mytilinaiou MG, Rigopoulou El, Bogdanos DP: PBC triggers in water reservoirs, coal mining areas and waste disposal sites: from Newcastle to New York. Dis Markers 2010, 29:337-344.

66. Triger DR: Primary biliary cirrhosis: an epidemiological study. Br Med J 1980, 281:772-775.

67. Amano K, Leung PS, Rieger R, Quan C, Wang X, Marik J, Suen YF, Kurth MJ, Nantz MH, Ansari AA, et al: Chemical xenobiotics and mitochondrial autoantigens in primary biliary cirrhosis: identification of antibodies against a common environmental, cosmetic, and food additive, 2octynoic acid. J Immunol 2005, 174:5874-5883.

68. Kouroumalis E: Environmental agents involved in the cause of primary biliary cirrhosis. Dis Markers 2010, 29:329-336.

69. Smyk D, Cholongitas E, Kriese S, Rigopoulou El, Bogdanos DP: Primary biliary cirrhosis: family stories. Autoimmune Dis 2011, 2011:189585.

70. Smyk D, Rigopoulou El, Baum H, Burroughs AK, Vergani D, Bogdanos DP: Autoimmunity and Environment: Am I at risk? Clin Rev Allergy Immunol 2011.

71. Smyk DS, Bogdanos DP, Kriese S, Billinis C, Burroughs AK, Rigopoulou El: Urinary tract infection as a risk factor for autoimmune liver disease: From bench to bedside. Clin Res Hepatol Gastroenterol 2011.

72. Siegel SM, Selmi C, Dottorini L, Antelmi M, Zuin M, Lanfredini M, Gershwin ME: Late-onset autoimmunity: the paradigm of primary biliary cirrhosis-a mini-review. Gerontology 2008, 54:193-201.

73. Hakim FT, Flomerfelt FA, Boyiadzis M, Gress RE: Aging, immunity and cancer. Curr Opin Immunol 2004, 16:151-156

74. Prelog $\mathrm{M}$ : Aging of the immune system: a risk factor for autoimmunity? Autoimmun Rev 2006, 5:136-139.

75. Fulop T, Larbi A, Dupuis G, Pawelec G: Ageing, autoimmunity and arthritis: Perturbations of TCR signal transduction pathways with ageing - a biochemical paradigm for the ageing immune system. Arthritis Res Ther 2003, 5:290-302.

76. Vallejo AN: CD28 extinction in human T cells: altered functions and the program of T-cell senescence. Immunol Rev 2005, 205:158-169.

77. Vallejo AN: Immunological hurdles of ageing: Indispensable research of the human model. Ageing Res Rev 2011

78. Weng NP, Akbar AN, Goronzy J: CD28(-) T cells: their role in the ageassociated decline of immune function. Trends Immunol 2009, 30:306-312.

79. Azuma M, Phillips JH, Lanier LL: CD28 co-stimulation of T-cell-mediated cytotoxicity. Int J Cancer Supp/ 1992, 7:33-35.

80. Goronzy JJ, Fulbright JW, Crowson CS, Poland GA, O'Fallon WM Weyand CM: Value of immunological markers in predicting 
responsiveness to influenza vaccination in elderly individuals. $J$ Virol 2001, 75:12182-12187.

81. Konya C, Goronzy JJ, Weyand CM: Treating autoimmune disease by targeting CD8(+) T suppressor cells. Expert Opin Biol Ther 2009, 9:951-965.

82. Bogdanos DP, Baum H, Butler P, Rigopoulou El, Davies ET, Ma Y, Burroughs AK, Vergani D: Association between the primary biliary cirrhosis specific anti-sp100 antibodies and recurrent urinary tract infection. Dig Liver Dis 2003, 35:801-805.

83. Bogdanos DP, Baum H, Grasso A, Okamoto M, Butler P, Ma Y, Rigopoulou E, Montalto P, Davies ET, Burroughs AK, Vergani D: Microbial mimics are major targets of crossreactivity with human pyruvate dehydrogenase in primary biliary cirrhosis. J Hepatol 2004, 40:31-39.

84. Bogdanos DP, Baum H, Gunsar F, Arioli D, Polymeros D, Ma Y, Burroughs AK, Vergani D: Extensive homology between the major immunodominant mitochondrial antigen in primary biliary cirrhosis and Helicobacter pylori does not lead to immunological cross-reactivity. Scand J Gastroenterol 2004, 39:981-987.

85. Bogdanos DP, Baum H, Sharma UC, Grasso A, Ma Y, Burroughs AK, Vergani D: Antibodies against homologous microbial caseinolytic proteases $\mathrm{P}$ characterise primary biliary cirrhosis. J Hepatol 2002, 36:14-21.

86. Bogdanos DP, Baum H, Vergani D, Burroughs AK: The role of E. coli infection in the pathogenesis of primary biliary cirrhosis. Dis Markers 2010, 29:301-311.

87. Bogdanos DP, Vergani D: Origin of cross-reactive autoimmunity in primary biliary cirrhosis. Liver Int 2006, 26:633-635.

88. Bogdanos DP, Vergani D: Bacteria and primary biliary cirrhosis. Clin Rev Allergy Immunol 2009, 36:30-39.

89. Burroughs AK, Rosenstein IJ, Epstein O, Hamilton-Miller JM, Brumfitt W, Sherlock S: Bacteriuria and primary biliary cirrhosis. Gut 1984, 25:133-137.

90. Selmi C, Gershwin ME: The role of environmental factors in primary biliary cirrhosis. Trends Immunol 2009, 30:415-420.

91. Shimoda S, Nakamura M, Shigematsu H, Tanimoto H, Gushima T, Gershwin ME, Ishibashi H: Mimicry peptides of human PDC-E2 163-176 peptide, the immunodominant T-cell epitope of primary biliary cirrhosis. Hepatology 2000, 31:1212-1216.

92. Bernuzzi $F$, Fenoglio D, Battaglia F, Fravega $M$, Gershwin $M E$, Indiveri $F$, Ansari AA, Podda M, Invernizzi P, Filaci G: Phenotypical and functional alterations of $\mathrm{CD} 8$ regulatory $\mathrm{T}$ cells in primary biliary cirrhosis. $J$ Autoimmun 2010, 35:176-180.

93. Georgin-Lavialle S, Aouba A, Mouthon L, Londono-Vallejo JA, Lepelletier Y, Gabet AS, Hermine O: The telomere/telomerase system in autoimmune and systemic immune-mediated diseases. Autoimmun Rev 2010, 9:646-651

94. Artlett CM, Black CM, Briggs DC, Stevens CO, Welsh KI: Telomere reduction in scleroderma patients: a possible cause for chromosomal instability. $\mathrm{Br}$ J Rheumatol 1996, 35:732-737.

95. Beier F, Balabanov S, Amberger CC, Hartmann U, Manger K, Dietz K, Kotter I, Brummendorf TH: Telomere length analysis in monocytes and lymphocytes from patients with systemic lupus erythematosus using multi-color flow-FISH. Lupus 2007, 16:955-962.

96. Colmegna I, Diaz-Borjon A, Fujii H, Schaefer L, Goronzy JJ, Weyand CM: Defective proliferative capacity and accelerated telomeric loss of hematopoietic progenitor cells in rheumatoid arthritis. Arthritis Rheum 2008, 58:990-1000

97. Honda M, Mengesha E, Albano S, Nichols WS, Wallace DJ, Metzger A, Klinenberg JR, Linker-Israeli M: Telomere shortening and decreased replicative potential, contrasted by continued proliferation of telomerase-positive CD8+CD28(lo) T cells in patients with systemic lupus erythematosus. Clin Immunol 2001, 99:211-221.

98. Koetz K, Bryl E, Spickschen K, O'Fallon WM, Goronzy JJ, Weyand CM: T cell homeostasis in patients with rheumatoid arthritis. Proc Natl Acad Sci USA 2000, 97:9203-9208.

99. Kurosaka D, Yasuda J, Yoshida K, Yokoyama T, Ozawa Y, Obayashi Y, Kingetsu I, Saito S, Yamada A: Telomerase activity and telomere length of peripheral blood mononuclear cells in SLE patients. Lupus 2003, 12:591-599.

100. Kurosaka D, Yasuda J, Yoshida K, Yoneda A, Yasuda C, Kingetsu I, Toyokawa Y, Yokoyama T, Saito S, Yamada A: Abnormal telomerase activity and telomere length in T and B cells from patients with systemic lupus erythematosus. J Rheumatol 2006, 33:1102-1107.
101. Maclntyre A, Brouilette SW, Lamb K, Radhakrishnan K, McGlynn L, Chee MM, Parkinson EK, Freeman D, Madhok R, Shiels PG: Association of increased telomere lengths in limited scleroderma, with a lack of age-related telomere erosion. Ann Rheum Dis 2008, 67:1780-1782.

102. Schonland SO, Lopez C, Widmann T, Zimmer J, Bryl E, Goronzy J, Weyand CM: Premature telomeric loss in rheumatoid arthritis is genetically determined and involves both myeloid and lymphoid cell lineages. Proc Natl Acad Sci USA 2003, 100:13471-13476.

103. Wu CH, Hsieh SC, Li K, Lu MC, Yu CL: Premature telomere shortening in polymorphonuclear neutrophils from patients with systemic lupus erythematosus is related to the lupus disease activity. Lupus 2007, 16:265-272.

104. Sasaki M, Ikeda H, Yamaguchi J, Nakada S, Nakanuma Y: Telomere shortening in the damaged small bile ducts in primary biliary cirrhosis reflects ongoing cellular senescence. Hepatology 2008, 48:186-195.

105. Katayama Y, Kohriyama K: Telomerase activity in peripheral blood mononuclear cells of systemic connective tissue diseases. J Rheumatol 2001, 28:288-291.

106. Tarhan F, Vural F, Kosova B, Aksu K, Cogulu O, Keser G, Gunduz C, Tombuloglu M, Oder G, Karaca E, Doganavsargil E: Telomerase activity in connective tissue diseases: elevated in rheumatoid arthritis, but markedly decreased in systemic sclerosis. Rheumatol Int 2008, 28:579-583.

107. Prelog M, Schwarzenbrunner N, Sailer-Hock M, Kern H, Klein-Franke A, Ausserlechner MJ, Koppelstaetter C, Brunner A, Duftner C, Dejaco C, et al: Premature aging of the immune system in children with juvenile idiopathic arthritis. Arthritis Rheum 2008, 58:2153-2162.

108. Kurosaka D, Yasuda J, Kingetsu I, Yasuda C, Yoshida K, Toyokawa Y, Yokoyama T, Yamada A: Two cases of adult Still's disease with abnormally high level of telomerase activity in peripheral blood mononuclear cells. Mod Rheumatol 2004, 14:394-398.

109. Vogt S, Iking-Konert C, Hug F, Andrassy K, Hansch GM: Shortening of telomeres: Evidence for replicative senescence of $\mathrm{T}$ cells derived from patients with Wegener's granulomatosis. Kidney Int 2003, 63:2144-2151.

110. Collado M, Blasco MA, Serrano M: Cellular senescence in cancer and aging. Cell 2007, 130:223-233.

111. Sasaki M, Nakanuma Y: Biliary epithelial apoptosis, autophagy, and senescence in primary biliary cirrhosis. Hepat Res Treat 2010, 2010:205128.

112. Sasaki M, Ikeda H, Haga H, Manabe T, Nakanuma Y: Frequent cellular senescence in small bile ducts in primary biliary cirrhosis: a possible role in bile duct loss. $J$ Pathol 2005, 205:451-459.

113. Sasaki M, Ikeda H, Nakanuma Y: Activation of ATM signaling pathway is involved in oxidative stress-induced expression of mito-inhibitory p21WAF1/Cip1 in chronic non-suppurative destructive cholangitis in primary biliary cirrhosis: an immunohistochemical study. J Autoimmun 2008, 31:73-78.

114. Sasaki M, Ikeda H, Sato Y, Nakanuma Y: Decreased expression of Bmi1 is closely associated with cellular senescence in small bile ducts in primary biliary cirrhosis. Am J Pathol 2006, 169:831-845.

115. Alvaro D, Mancino MG, Glaser S, Gaudio E, Marzioni M, Francis H, Alpini G: Proliferating cholangiocytes: a neuroendocrine compartment in the diseased liver. Gastroenterology 2007, 132:415-431.

116. Isse K, Harada K, Zen Y, Kamihira T, Shimoda S, Harada M, Nakanuma Y: Fractalkine and CX3CR1 are involved in the recruitment of intraepithelial lymphocytes of intrahepatic bile ducts. Hepatology 2005, 41:506-516.

117. Sasaki M, Miyakoshi M, Sato Y, Nakanuma Y: Modulation of the microenvironment by senescent biliary epithelial cells may be involved in the pathogenesis of primary biliary cirrhosis. J Hepatol 2010, 53:318-325.

118. Tsuneyama K, Harada K, Yasoshima M, Hiramatsu K, Mackay CR, Mackay IR, Gershwin ME, Nakanuma Y: Monocyte chemotactic protein-1, -2 , and -3 are distinctively expressed in portal tracts and granulomata in primary biliary cirrhosis: implications for pathogenesis. J Pathol 2001, 193:102-109.

119. Sasaki M, Miyakoshi M, Sato Y, Nakanuma Y: Autophagy mediates the process of cellular senescence characterizing bile duct damages in primary biliary cirrhosis. Lab Invest 2010, 90:835-843.

120. Levine B, Kroemer G: Autophagy in the pathogenesis of disease. Cell 2008, 132:27-42

121. Mizushima N: Autophagy: process and function. Genes Dev 2007, 21:2861-2873.

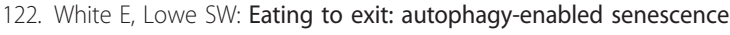
revealed. Genes Dev 2009, 23:784-787. 
123. Yin XM, Ding WX, Gao W: Autophagy in the liver. Hepatology 2008, 47:1773-1785.

124. Munoz LE, Lauber K, Schiller M, Manfredi AA, Herrmann M: The role of defective clearance of apoptotic cells in systemic autoimmunity. Nat Rev Rheumatol 2010, 6:280-289.

125. Schulze C, Munoz LE, Franz S, Sarter K, Chaurio RA, Gaipl US, Herrmann M: Clearance deficiency-a potential link between infections and autoimmunity. Autoimmun Rev 2008, 8:5-8.

126. Lauber K, Bohn E, Krober SM, Xiao YJ, Blumenthal SG, Lindemann RK, Marini P, Wiedig C, Zobywalski A, Baksh S, et al: Apoptotic cells induce migration of phagocytes via caspase-3-mediated release of a lipid attraction signal. Cell 2003, 113:717-730.

127. Savill J: Apoptosis in resolution of inflammation. J Leukoc Biol 1997, 61:375-380.

128. Voll RE, Herrmann M, Roth EA, Stach C, Kalden JR, Girkontaite I: Immunosuppressive effects of apoptotic cells. Nature 1997, 390:350-351.

129. Herrmann M, Voll RE, Zoller OM, Hagenhofer M, Ponner BB, Kalden JR: Impaired phagocytosis of apoptotic cell material by monocyte-derived macrophages from patients with systemic lupus erythematosus. Arthritis Rheum 1998, 41:1241-1250.

130. Rosen A, Casciola-Rosen L: Autoantigens as substrates for apoptotic proteases: implications for the pathogenesis of systemic autoimmune disease. Cell Death Differ 1999, 6:6-12.

131. Svensson B: Occurrence of deficient monocyte yeast cell phagocytosis in presence of rheumatic sera. Scand J Rheumatol Supp/ 1980, 31:21-27.

132. Allina J, Hu B, Sullivan DM, Fiel MI, Thung SN, Bronk SF, Huebert RC, van de Water J, LaRusso NF, Gershwin ME, et al: T cell targeting and phagocytosis of apoptotic biliary epithelial cells in primary biliary cirrhosis. $J$ Autoimmun 2006, 27:232-241.

133. Heyder P, Bekeredjian-Ding I, Parcina M, Blank N, Ho AD, Herrmann M, Lorenz HM, Heeg K, Schiller M: Purified apoptotic bodies stimulate plasmacytoid dendritic cells to produce IFN-alpha. Autoimmunity 2007 40:331-332.

134. Lleo A, Bowlus CL, Yang GX, Invernizzi P, Podda M, Van de Water J, Ansari AA, Coppel RL, Worman HJ, Gores GJ, Gershwin ME: Biliary apotopes and anti-mitochondrial antibodies activate innate immune responses in primary biliary cirrhosis. Hepatology 2010, 52:987-998.

135. Lleo A, Selmi C, Invernizzi P, Podda M, Coppel RL, Mackay IR, Gores GJ, Ansari AA, Van de Water J, Gershwin ME: Apotopes and the biliary specificity of primary biliary cirrhosis. Hepatology 2009, 49:871-879

136. Odin JA, Huebert RC, Casciola-Rosen L, LaRusso NF, Rosen A: Bcl-2dependent oxidation of pyruvate dehydrogenase-E2, a primary biliary cirrhosis autoantigen, during apoptosis. J Clin Invest 2001, 108:223-232.

137. Radic M, Marion T, Monestier M: Nucleosomes are exposed at the cell surface in apoptosis. J Immunol 2004, 172:6692-6700.

138. Schiller M, Bekeredjian-Ding I, Heyder P, Blank N, Ho AD, Lorenz HM: Autoantigens are translocated into small apoptotic bodies during early stages of apoptosis. Cell Death Differ 2008, 15:183-191.

139. Baumann I, Kolowos W, Voll RE, Manger B, Gaipl U, Neuhuber WL, Kirchner T, Kalden JR, Herrmann M: Impaired uptake of apoptotic cells into tingible body macrophages in germinal centers of patients with systemic lupus erythematosus. Arthritis Rheum 2002, 46:191-201.

140. Hepburn AL, Lampert IA, Boyle JJ, Horncastle D, Ng WF, Layton M, Vyse TJ, Botto $\mathrm{M}$, Mason JC: In vivo evidence for apoptosis in the bone marrow in systemic lupus erythematosus. Ann Rheum Dis 2007, 66:1106-1109.

141. Kuhn A, Herrmann M, Kleber S, Beckmann-Welle M, Fehsel K, MartinVillalba A, Lehmann P, Ruzicka T, Krammer PH, Kolb-Bachofen V: Accumulation of apoptotic cells in the epidermis of patients with cutaneous lupus erythematosus after ultraviolet irradiation. Arthritis Rheum 2006, 54:939-950.

142. Lorenz HM, Grunke M, Hieronymus T, Herrmann M, Kuhnel A, Manger B, Kalden JR: In vitro apoptosis and expression of apoptosis-related molecules in lymphocytes from patients with systemic lupus erythematosus and other autoimmune diseases. Arthritis Rheum 1997, 40:306-317.

143. Koga H, Sakisaka S, Ohishi M, Sata M, Tanikawa K: Nuclear DNA fragmentation and expression of $\mathrm{BCl}-2$ in primary biliary cirrhosis. Hepatology 1997, 25:1077-1084.

144. Kuroki T, Seki S, Kawakita N, Nakatani K, Hisa T, Kitada T, Sakaguchi H: Expression of antigens related to apoptosis and cell proliferation in chronic nonsuppurative destructive cholangitis in primary biliary cirrhosis. Virchows Arch 1996, 429:119-129.

145. Gershwin ME, Selmi C, Worman HJ, Gold EB, Watnik M, Utts J, Lindor KD, Kaplan MM, Vierling JM: Risk factors and comorbidities in primary biliary cirrhosis: a controlled interview-based study of 1032 patients. Hepatology 2005, 42:1194-1202.

146. Butler P, Valle F, Hamilton-Miller JM, Brumfitt W, Baum H, Burroughs AK: M2 mitochondrial antibodies and urinary rough mutant bacteria in patients with primary biliary cirrhosis and in patients with recurrent bacteriuria. $J$ Hepatol 1993, 17:408-414

147. Varyani FK, West J, Card TR: An increased risk of Urinary Tract Infection precedes development of Primary Biliary Cirrhosis. BMC Gastroenterol 2011, 11:95

148. Matthews SJ, Lancaster JW: Urinary Tract Infections in the Elderly Population. Am J Geriatr Pharmacother 2011

149. Hopf U, Moller B, Stemerowicz R, Lobeck H, Rodloff A, Freudenberg M, Galanos C, Huhn D: Relation between Escherichia coli R(rough)-forms in gut, lipid A in liver, and primary biliary cirrhosis. Lancet 1989, 2:1419-1422

150. Vergani $D$, Bogdanos DP, Baum $H$ : Unusual suspects in primary biliary cirrhosis. Hepatology 2004, 39:38-41

151. Vergani D, Choudhuri K, Bogdanos DP, Mieli-Vergani G: Pathogenesis of autoimmune hepatitis. Clin Liver Dis 2002, 6:727-737.

152. Ma Y, Thomas MG, Okamoto M, Bogdanos DP, Nagl S, Kerkar N, Lopes AR, Muratori L, Lenzi M, Bianchi FB, et al: Key residues of a major cytochrome P4502D6 epitope are located on the surface of the molecule. $J$ Immunol 2002, 169:277-285.

153. Gregorio GV, Choudhuri K, Ma Y, Pensati P, lorio R, Grant P, Garson J, Bogdanos DP, Vegnente A, Mieli-Vergani G, Vergani D: Mimicry between the hepatitis $C$ virus polyprotein and antigenic targets of nuclear and smooth muscle antibodies in chronic hepatitis $C$ virus infection. Clin Exp Immunol 2003, 133:404-413.

154. Gregorio GV, Choudhuri K, Ma Y, Vegnente A, Mieli-Vergani G, Vergani D: Mimicry between the hepatitis B virus DNA polymerase and the antigenic targets of nuclear and smooth muscle antibodies in chronic hepatitis B virus infection. J Immunol 1999, 162:1802-1810.

155. Kerkar N, Choudhuri K, Ma Y, Mahmoud A, Bogdanos DP, Muratori L, Bianchi F, Williams R, Mieli-Vergani G, Vergani D: Cytochrome P4502D6 (193-212): a new immunodominant epitope and target of virus/self cross-reactivity in liver kidney microsomal autoantibody type 1-positive liver disease. J Immunol 2003, 170:1481-1489.

156. Bogdanos DP, Muratori L, Bianchi FB, Vergani D: Hepatitis C virus and autoimmunity. Hepatology 2000, 31:1380.

157. Bogdanos DP, Dalekos GN: Enzymes as target antigens of liver-specific autoimmunity: the case of cytochromes P450s. Curr Med Chem 2008, 15:2285-2292.

158. Bogdanos DP, McFarlane IG: Cytochrome P450 2A6 meets P450 2D6: an enigma of viral infections and autoimmunity. J Hepatol 2003, 39:860-863.

159. Bogdanos DP, Lenzi M, Okamoto M, Rigopoulou El, Muratori P, Ma Y, Muratori L, Tsantoulas D, Mieli- Vergani G, Bianchi FB, Vergani D: Multiple $\mathrm{viral} / \mathrm{self}$ immunological cross-reactivity in liver kidney microsomal antibody positive hepatitis $C$ virus infected patients is associated with the possession of HLA B51. Int J Immunopathol Pharmacol 2004, 17:83-92

160. Muratori L, Bogdanos DP, Muratori P, Lenzi M, Granito A, Ma Y, MieliVergani G, Bianchi FB, Vergani D: Susceptibility to thyroid disorders in hepatitis C. Clin Gastroenterol Hepatol 2005, 3:595-603.

161. Baum $\mathrm{H}$ : Nature of the mitochondrial antigens of primary biliary cirrhosis and their possible relationships to the etiology of the disease. Semin Liver Dis 1989, 9:117-123.

162. Butler $\mathrm{P}$, Hamilton-Miller J, Baum H, Burroughs AK: Detection of M2 antibodies in patients with recurrent urinary tract infection using an ELISA and purified PBC specific antigens. Evidence for a molecular mimicry mechanism in the pathogenesis of primary biliary cirrhosis? Biochem Mol Biol Int 1995, 35:473-485.

163. Baum H, Bogdanos DP, Vergani D: Antibodies to Clp protease in primary biliary cirrhosis: possible role of a mimicking T-cell epitope. J Hepatol 2001, 34:785-787.

164. Mayo I, Arizti P, Pares A, Oliva J, Doforno RA, de Sagarra MR, Rodes J, Castano JG: Antibodies against the $\mathrm{COOH}$-terminal region of $\mathrm{E}$. coli ClpP protease in patients with primary biliary cirrhosis. $J$ Hepatol 2000 33:528-536. 
165. Shimoda S, Nakamura M, Ishibashi H, Hayashida K, Niho Y: HLA DRB4 0101restricted immunodominant $\mathrm{T}$ cell autoepitope of pyruvate dehydrogenase complex in primary biliary cirrhosis: evidence of molecular mimicry in human autoimmune diseases. J Exp Med 1995, 181:1835-1845

166. Shimoda S, Van de Water J, Ansari A, Nakamura M, Ishibashi H, Coppel RL, Lake J, Keeffe EB, Roche TE, Gershwin ME: Identification and precursor frequency analysis of a common $T$ cell epitope motif in mitochondrial autoantigens in primary biliary cirrhosis. J Clin Invest 1998, 102:1831-1840.

167. Bogdanos DP, Baum H, Okamoto M, Montalto P, Sharma UC, Rigopoulou El, Vlachogiannakos J, Ma Y, Burroughs AK, Vergani D: Primary biliary cirrhosis is characterized by lgG3 antibodies cross-reactive with the major mitochondrial autoepitope and its Lactobacillus mimic. Hepatology 2005, 42:458-465.

168. Bernier M, Njomnang Soh P, Lochet A, Prots L, Felice R, Senescau A, Fabre R, Philippon A: [Lactobacillus delbrueckii: Probable agent of urinary tract infections in very old women.]. Pathol Biol (Paris) 2010.

169. Darbro BW, Petroelje BK, Doern GV: Lactobacillus delbrueckii as the cause of urinary tract infection. J Clin Microbiol 2009, 47:275-277.

170. Selmi C, Balkwill DL, Invernizzi P, Ansari AA, Coppel RL, Podda M, Leung PS, Kenny TP, Van De Water J, Nantz MH, et al: Patients with primary biliary cirrhosis react against a ubiquitous xenobiotic-metabolizing bacterium. Hepatology 2003, 38:1250-1257.

171. Mattner J, Savage PB, Leung P, Oertelt SS, Wang V, Trivedi O, Scanlon ST, Pendem $\mathrm{K}$, Teyton $\mathrm{L}$, Hart J, et al: Liver autoimmunity triggered by microbial activation of natural killer T cells. Cell Host Microbe 2008, 3:304-315

172. Stellon AJ, Williams R: Increased incidence of menstrual abnormalities and hysterectomy preceding primary biliary cirrhosis. Br Med J 1986, 293:297-298.

173. Parikh-Patel A, Gold E, Utts J, Gershwin ME: The association between gravidity and primary biliary cirrhosis. Ann Epidemiol 2002, 12:264-272.

174. Alvaro D, Invernizzi P, Onori P, Franchitto A, De Santis A, Crosignani A, Sferra R, Ginanni-Corradini S, Mancino MG, Maggioni M, et al: Estrogen receptors in cholangiocytes and the progression of primary biliary cirrhosis. J Hepatol 2004, 41:905-912.

175. Alvaro D, Mancino MG, Onori P, Franchitto A, Alpini G, Francis H, Glaser S, Gaudio E: Estrogens and the pathophysiology of the biliary tree. World J Gastroenterol 2006, 12:3537-3545.

176. Alvaro D, Onori P, Metalli VD, Svegliati-Baroni G, Folli F, Franchitto A, Alpini G, Mancino MG, Attili AF, Gaudio E: Intracellular pathways mediating estrogen-induced cholangiocyte proliferation in the rat. Hepatology 2002, 36:297-304.

177. Guattery JM, Faloon WW: Effect of estradiol upon serum enzymes in primary biliary cirrhosis. Hepatology 1987, 7:737-742

178. Mason AL: The evidence supports a viral aetiology for primary biliary cirrhosis. J Hepatol 2011, 54:1312-1314.

179. Mason AL, Zhang G: Linking human beta retrovirus infection with primary biliary cirrhosis. Gastroenterol Clin Biol 2010, 34:359-366.

180. Montano-Loza AJ, Wasilenko S, Bintner J, Mason AL: Cyclosporine A inhibits in vitro replication of betaretrovirus associated with primary biliary cirrhosis. Liver Int 2010, 30:871-877.

181. Mason AL, Xu L, Guo L, Munoz S, Jaspan JB, Bryer-Ash M, Cao Y, Sander DM, Shoenfeld $Y$, Ahmed A, et al: Detection of retroviral antibodies in primary biliary cirrhosis and other idiopathic biliary disorders. Lancet 1998, 351:1620-1624.

182. Mason A, Xu L, Shen Z, Fodera B, Joplin R, Neuberger J, O'Donnell B: Patients with primary biliary cirrhosis make anti-viral and antimitochondrial antibodies to mouse mammary tumor virus. Gastroenterology 2004, 127:1863-1864, author reply 1864-1865.

183. Xu L, Shen Z, Guo L, Fodera B, Keogh A, Joplin R, O'Donnell B, Aitken J, Carman W, Neuberger J, Mason A: Does a betaretrovirus infection trigger primary biliary cirrhosis? Proc Natl Acad Sci USA 2003, 100:8454-8459.

184. Selmi C, Ross SR, Ansari AA, Invernizzi P, Podda M, Coppel RL, Gershwin ME: Lack of immunological or molecular evidence for a role of mouse mammary tumor retrovirus in primary biliary cirrhosis. Gastroenterology 2004, 127:493-501.

185. Johal H, Scott GM, Jones R, Camaris C, Riordan S, Rawlinson WD: Mouse mammary tumour virus-like virus (MMTV-LV) is present within the liver in a wide range of hepatic disorders and unrelated to nuclear p53 expression or hepatocarcinogenesis. J Hepatol 2009, 50:548-554
186. Sadamoto T, Joplin R, Keogh A, Mason A, Carman W, Neuberger J: Expression of pyruvate-dehydrogenase complex PDC-E2 on biliary epithelial cells induced by lymph nodes from primary biliary cirrhosis. Lancet 1998, 352:1595-1596.

187. Wasilenko ST, Mason GE, Mason AL: Primary biliary cirrhosis, bacteria and molecular mimicry: what's the molecule and where's the mimic? Liver Int 2009, 29:779-782.

188. Mason AL, Farr GH, Xu L, Hubscher SG, Neuberger JM: Pilot studies of single and combination antiretroviral therapy in patients with primary biliary cirrhosis. Am J Gastroenterol 2004, 99:2348-2355.

189. Mason AL, Wasilenko ST: Other potential medical therapies: the use of antiviral agents to investigate and treat primary ciliary cirrhosis. Clin Liver Dis 2008, 12:445-460, xi.

190. Mason AL, Lindor KD, Bacon BR, Vincent C, Neuberger JM, Wasilenko ST: Clinical Trial: Randomized controlled trial of zidovudine and lamivudine for patients with primary biliary cirrhosis stabilized on ursodiol. Aliment Pharmacol Ther 2008

191. Selmi C: The evidence does not support a viral etiology for primary biliary cirrhosis. J Hepatol 2011, 54:1315-1316.

doi:10.1186/1742-4933-8-12

Cite this article as: Smyk et al:: Immunopathogenesis of primary biliary cirrhosis: an old wives' tale. Immunity \& Ageing 2011 8:12.

\section{Submit your next manuscript to BioMed Central and take full advantage of:}

- Convenient online submission

- Thorough peer review

- No space constraints or color figure charges

- Immediate publication on acceptance

- Inclusion in PubMed, CAS, Scopus and Google Scholar

- Research which is freely available for redistribution

Submit your manuscript at www.biomedcentral.com/submit
C) Biomed Central 